\title{
POČECI SUVREMENE PLESNE SCENE U ZAGREBU 1924. - 1930. I 1945. - 1967.
}

\section{Maja Đurinović}

\author{
UDK: 793.3(497.5)“192/196“ \\ Pregledni članak
}

Sažetak: Ovim se radom želi proširiti doživljaj i pojam Zagreba kao nesumnjivog kulturnog centra u objema Jugoslavijama na temelju diskursa povijesti plesa - umjetnosti koja se tijekom 20. stoljeća izborila za autonomnost i društveni status. Godine koje je Vladan Desnica proveo u Zagrebu zadiru u dva perioda europeizacije i duhovnog širenja grada: usvajanja novih interesa, umjetničkih ideja i praksi, među kojima je i plesna umjetnost. Zagreb je grad s upisanom memorijom habsburškog Agrama. „Mali Beč“ u razdoblju između dvaju svjetskih ratova hvata korak s europskim uzorima, što se u plesnoj praksi ogleda u izražajnom, ekspresivnom plesu (tzv. Ausdruckstanz) kao dominantnom stilu plesnog modernizma. Istovremeno se, konačno, pod vodstvom ruske baletne umjetnice Margarite Froman formira i nacionalni balet u HNK-u u Zagrebu te se dobiva uvid u baletni repertoar, koji se pojavom Ballets Russes uspostavio na europskoj sceni 20. stoljeća. Nakon ratne destrukcije i političkih promjena radi se na što bržoj uspostavi kulturnih institucija, koje će predstavljati tekovine mlade države SFRJ. U Zagrebu otvaraju se Baletna škola i Škola za ritmiku i ples te uz rijetke, ali značajne gostujuće pedagoge, dolazi do vidljivog pomaka u profesionalizaciji struke. Kako granice spram Zapada postaju propusnije, tako se Zagreb 1960-ih ponovno uzdiže kao kulturno središte i ishodište novih tendencija, unutar čega se formira i respektabilna baletna, ali i avangardna suvremena plesna scena.

Ključne riječi: Balet HNK-a u Zagrebu, plesni modernizam, nezavisna plesna scena

I. I924. - I930.

\section{1. Razvoj nacionalnog baleta}

ovijest hrvatske plesne scene specifična je po tome što se zapravo usporedno razvijaju balet i moderni ples. U klasičnom baletu Zagreb, bez obzira na nekoliko entuzijastičkih pothvata, kasni nekoliko stotina godina (što i nije čudno jer su političke i kulturne prijestolnice u Beču i Budimpešti, a rituali i plemenita dokolica bogatih dvorova nepoznati) 
i 1920-ih konačno hvata korak s Europom. Ključan je trenutak gostovanje ruske balerine Margarite Froman, koja nakon zamijećenih nastupa u Kazalištu početkom 1921. sa svojom skupinom ostaje u Zagrebu. U to vrijeme, nakon Revolucije, ruska baletna emigracija se razmiljela Europom, a onda i dalje po svijetu, koristeći se i ujedno šireći popularnost Ballets Russes Sergeja Djagiljeva, fenomena koji je uistinu promijenio povijest baleta. Froman je bila izvrsna balerina s iskustvom i repertoarom Ballets Russes te skupine Ane Pavlove, a pokazalo se i da je vrsna kao pedagoginja, koreografkinja i redateljica. Obrazuje plesače i odgaja publiku te u kratkom roku priprema ansambl za djela koja su u to vrijeme poznati naslovi baletnog repertoara europskih kazališta ${ }^{1}$, a uz ruske su soliste spretno prilagođena mogućnostima zagrebačkog ansambla. Također, ona istražuje i upija nacionalne odlike hrvatskog plesa te u suradnji s kompozitorom i dirigentom Krešimirom Baranovićem i slikarom Maksimilijanom Vankom znalački obrađuje folklorne teme te već 1924. postavlja baletnu jednočinku Licitarsko srce, prvo antologijsko djelo hrvatskog baleta, nacionalni spektakl i reprezentativno djelo idealno za promociju hrvatskog plesa, poletnog, vedrog i duhovitog karaktera, maštovitih i ljupkih koreografskih detalja, posebno u smislu stilizacije folklornih elemenata i poznatih etno motiva iz hrvatske glazbeno-plesne i likovne baštine ${ }^{2}$. Fromanova u tom prvom periodu ${ }^{3}$ postavlja još nekoliko koreografija na glazbu suvremenih hrvatskih kompozitora: Sjene B. Širole (1923.), Cvijeće male Ide K. Baranovića (1925.), Figurine L. Šafraneka-Kavića (1926.). U tim koreografijama bilježi prve nastupe mala Mia Čorak, kasnije prva domaća primabalerina i svjetska baletna diva - Slavenska, koju M. Froman, a ubrzo i kritika i publika prepoznaju kao izniman talent ${ }^{4}$. Mia Čorak je definitivno bila čudo od djeteta: $s$ dvanaest godina počinje održavati plesne priredbe i solističke baletne večeri, a kada Margarita Froman odlazi u Beograd, ona nastavlja edukaciju u Beču u znamenitoj školi izražajnog plesa Gertrude Kraus. Nakon povratka u Zagreb, Mia 9. studenoga 1928. nastupa u Glazbenom zavodu te postiže ogroman uspjeh. Pavao Markovac će pola godine kasnije ${ }^{5}$, nakon jednog drugog nastupa mlade balerine, primijetiti:

U groteski jednako uspjela kao klasičnom baletu i u plesu modernijeg smjera, Mia Čorak ima toliko razvijenu tehniku na vršcima prstiju, da je upravo nerazumljivo, kako se plesačicama slabijeg ranga mogu povjeriti onakve zadaće kao recimo u Kopeliji. Mia Čorak može mirno da pleše u Žar ptici (...) Glavna bi stvar bila da mlada plesačica pođe u inozemstvo, da upozna novije plesne smjerove i razvije svoj individualitet. Kazališna uprava svakako ništa ne čini, da barem indirektno omogući ove studije.

$1 \quad$ Poput Vizije noći na Chopinovu glazbu, II. i IV. čin Labuđeg jezera P. I. Čajkovskog, Saint-Saënsova Smrt labuda, Kopelija L. Delibesa, Šeherezada N. A. Rimski-Korsakova, Polovjecki plesovi A. P. Borodina, scene iz Ščelkunčika P. I. Čajkovskog, Petruška I. F. Stravinskog, Karneval R. Schumanna, Capriccio Espagnol N. A. Rimski-Korsakova, Pan Twardowski L. Różyckija, Kutija igračaka C. Debussyja. Više u Maja Đurinović, „Balet“, u: Hrvatsko narodno kazalište u Zagrebu 1840 - 1860 - 1992, Zagreb 1992., 153-181.

2 Vanka je kostime i scenografiju oblikovao na temu pokupske nošnje i u bojama licitara. Zvjezdana Antoš, autorica izložbe u katalogu Zbirke slika Etnografskog muzeja u Zagrebu (2017.), bilježi da je Vanka oduševljeno sudjelovao u istraživačkoj tzv. Pokupskoj ekspediciji 1923., kada su nastale slike i crteži u svrhu etnografskog proučavanja.

argarita Froman je od 1927. do 1930. angažirana u beogradskom Baletu, gdje za početak prenosi Licitarsko srce.

4 Mia Čorak postat će prva domaća primabalerina, ali će ubrzo nakon toga, gubitkom političke naklonosti, biti protjerana iz Kazališta, što će u konačnici, preko Pariza do Los Angelesa, rezultirati neponovljivom svjetskom karijerom. Više u: M. Đurinović i Zvonimir Podkovac, Mia Črak Slavenska, Zagreb 2004.

5 „Plesno veče Mie Čorak, Vanredan uspjeh mlade plesačice“, Novosti (Beograd), 11. 11. 1928., preuzeto iz brošure Mia Črak / brošura, izbor kritika baletnih nastupa Mie Čorak od 1922. do 1932., 1933. [?], 7-8. 
Mia Čorak je o svom trošku otišla na daljnje baletne studije u Pariz te je kasnije na kratko vrijeme preuzela ulogu Žar-ptice.

\section{2. Počeci plesnog modernizma}

Iako su se prvi plesni koncerti modernog plesnog izraza u Zagrebu održavali i koju godinu ranije, 1924. je ključna u rekonstrukciji početaka suvremenog plesa zbog gostovanja Rudolfa Labana, umjetnika, vizionara i plesnog revolucionara, čiji je rad, dotičući se praktički svih zamislivih aspekata - radikalno promijenio razumijevanje plesa u 20. stoljeću. Vjerujemo da dio zasluga za jugoslavensku turneju i izniman prijam u Zagrebu pripada plesačici Veri Milčinović, kasnije u Americi poznatoj pod umjetničkim imenom Tashamira ${ }^{6}$, koja je tijekom studija u Labanovoj školi u Hamburgu postala članicom njegove Tanzbühne. Osim dogovorenih programa u kazalištu, Labanova grupa je 21. svibnja 1924. nastupila i na otvorenju Proljetnog salona u Umjetničkom paviljonu. Tom je prigodom Laban održao predavanja o „novoj plesnoj umjetnosti“, koja je samostalna umjetnost te može postojati i bez vanjskih poticaja ili ograničenja poput glazbe, radnje, sadržaja i kostima. „Na taj način biva apsolutni ples najčišćom umjetničkom tvorevinom" "7 kaže Laban, a javno ga podržavaju Josip Kulundžić (koji za Scenu piše tekst o novom plesu) i Kalman Mesarić:

Bila je bez sumnje sretna ideja, što se predavanje i ova kratka manifestacija apsolutnoga plesa smjestila u okvir izložbe Proljetnog Salona. Labanova eksplikacija apsolutnog plesa bila je ujedno indirektna eksplikacija onih slika koje su visile oko plesnog podija, a kada su članovi Labanovog teatra ritmodinamičkim pokretima manifestovali svoje umjetničke doživljaje, ritam je Sumanovićevih slika oživio. Plastika je progovorila pokretno. Ukratko: za nas je Laban otkrivenje i snažan umjetnički doživljaj. ${ }^{8}$

Laban je tako potaknuo vrlo napredna promišljanja plesa u kontekstu likovne i kazališsne kritike. „Ples“ ovdje znači kretanje uopće; to je igra par excellence; sugestivna umjetnost koja je izazvala napeti muk u publici najviše tijekom „novatorskih“ koreografija bez glazbe; apsolutni ples ne treba nikakvu vanjsku pratnju ili ukras; tijelo se dinamično upisuje u prostor, oblikuje ga i komunicira s njim ${ }^{9}$, osviješteno otkrivajući kombinacije kvaliteta pokreta $^{10}$; tijekom izvedbe publika osjeća tjelesnu rezonanciju onog što se događa na pozornici; prepoznat je stilizirani ekspresionizam, struktura malih formi i slobodne kompozicije

6 Vera Milčinović Tashamira (Zagreb, 20. kolovoza 1906. - Rodeo, CA, 24. ožujka 1995.), kći hrvatskih književnika Adele i Andrije Milčinovića, plesačica i koreografkinja. Učila balet kod M. Froman, plesne studije nastavila u Hellerauu kod Jaquesa-Dalcrozea, da bi završila trogodišnji studij u Hamburgu kod čuvenog reformatora plesa R. Labana. Tijekom studija postaje članica njegove Tanzbühne i gostuje po cijeloj Europi. Od 1926. nastupa samostalno u SAD-u te drži radionice i predavanja o novom plesu. Prva je plesačica na američkoj televiziji. Više u: M. ĐurINović, „Vera Milčinović Tashamira: Plesna umjetnica koja je donijela europski izražajni ples u Ameriku (Zvali su je Croatian Beauty)“, u: Krležini dani u Osijeku 2016. Hrvatska drama i kazalište u inozemstvu: drugi dio, Zagreb - Osijek 2017.

7 Scena (Zagreb), 21. 5. 1924., 6.

8 Kalman Mesarić, „Apsolutni ples. Gostovanje teatra R de Labana“, Slobodna tribuna (Zagreb), br. 538, 24. 5. 1924., 11.

9 Labanova teorija prostorne harmonije zove se koreutika.

10 Labanova eukinetika obuhvaća sveukupnu izražajnost pokreta baziranu na faktorima prostora, vremena, jačine i tijeka. 
izražaja pokretom i linijom tijela i udova, Labanova neumorna radoznalost u istraživanju motiva i oblika ljudskih manifestacija.

$S$ druge strane, Laban je definitivno čovjek svog vremena: početkom 20. stoljeća u Austriji i Njemačkoj u tijeku su veliki društveni pokreti Reforme života (Lebensreform) ${ }^{11}$ koji su uključivali „razne alternativne načine života (...) i brojne umjetničke pokrete“12, uz koje se posvještava i razvija kultura tijela (Körperkultur), iz čega će se razviti osnovne postavke i metodologije njemačkog modernog ili ekspresivnog plesa Ausdruckstanza. U Labanovoj modernističkoj viziji svatko može i treba plesati, treba obnoviti zajedništvo plesnog kora (Bewegungschor) i kulturu svečanosti u prirodi (Festkultur), kako bi se uspješno suprotstavilo otuđenju i osamljenosti unutar suvremenog društva. Modernisti se zanimaju za poganske korijene plesa sačuvane u folkloru različitih nacija i zajednica, istražuju transičnu i ekstatičnu, zaumnu moć plesa.

Ovaj veliki društveni pokret oslobađanja prirodnosti tijela uključuje i ravnopravnost tijela te je moderni ples Isadore Duncan u velikom dijelu ženski izraz i prilika za autonomno djelovanje plesnih umjetnica. Beč je bio centar „novog plesa“, koji je

nastao na razmeđi mnogostrukih nastojanja reformiranja života tog vremena sa sviješću o „cjelovitosti“ ljudskog bitka - emancipaciji žena, gimnastici, upravi školstva, pokretu higijene tijela (...) „Slobodan“ je trebao biti taj ples - prema još neartikuliranom osjećaju mnogih - slobodan od institucionaliziranog grčevitog stiska operne kuće, slobodan od kazališnih i društvenih igranja uloga prošlih stoljeća, konačno oslobođen ograničavajućeg sputavanja korzeta. Čovjek je htio sam takoreći tijelom doći do riječi, htio je izraziti svoje osjećaje, emocije i raspoloženja - upravo vlastitu osobnost ${ }^{13}$.

Zagreb je trebao biti samo prva stanica Labanove jugoslavenske turneje, no ispalo je da se nakon dogovorenih gostovanja u Beogradu, Novom Sadu i Osijeku Tanzbühne vratila u Zagreb te je Laban, umjesto šest dana, ovdje na nekoj vrsti rezidencije proveo šest tjedana, održavši i seminar za plesnu struku, kao i za neplesače, a iz jednog novinskog članka saznajemo da se svakom novom predstavom održanom u kazalištu u Tuškancu „broj labanista povećava". ${ }^{14}$

Znamo (ali nije još detaljno istraženo) da u tom periodu u Zagrebu Školu modernog plesa po Labanu otvara Elisabeth (Jelisava) Törne, u kojoj 1925., prije odlaska u Ameriku, predaje i Vera Milčinović, a koju pohađaju Claudia Fritzi Vall, Alma Hirschl (kasnije umjetnički Jelenska) i Mercedes Goritz Pavelić - koje će, nakon povratka iz europskih akademija, 1930-ih nastaviti djelovati kao samostalne, etablirane (i međunarodno uspješne) plesne umjetnice - da bi se izgubile tijekom Drugog svjetskog rata, no tek smo im nedavno počeli ulaziti u trag.

$\overline{11}$ Jedna od takvih utopističkih komuna bila je ona u Monte Verità kraj Ascone u Švicarskoj koja je privukla brojne umjetnike poput Jamesa Joycea, Ericha Marije Remarquea, Hermana Hessea i Rudolfa Labana, a tu su boravili i Carl Gustav Jung te Lenjin. V. Iva Nerina Sibila, „Ples je rasno pitanje / Rudolf Laban i nacistički režim“, Kretanja, 27/2017., 25-31.

12 Isto, 25.

13 Andrea Amort i Mimi Wunderer-Gosch, Österreich tanzt. Geschichte und Gegenwart, Beč 2001., 54; preuzeto iz: Katarina ŽeravicA, „Škola za ritmičku gimnastiku i umjetnički ples Gertrud Kraus“, Književna revija, 56/2016., br. $1-2,34$.

14 Vinko Jurković, „Kazalište i umjetnost“, Slobodna tribuna (Zagreb), br. 542, 21. 6. 1924., 6. 


\section{2. $1945 .-1967$.}

\section{1. Baletna scena}

Odmah nakon završetka rata Kazalište je krenulo u popunjavanje bitno osiromašenog baletnog ansambla i davanje programa. Margarita Froman angažirala je još maloljetne djevojčice $^{15} s$ kojima je radila balet u Dječjem carstvu i Umjetničkoj školi, a iz područja sporta i folklora regrutiraju se talentirani mladići. (U vrijeme velike i opće neimaštine rad u Kazalištu osiguravao je egzistenciju.)

Taj prvi poslijeratni period u znaku je Ane Roje kao neupitnog međunarodnog umjetničkog autoriteta, s jakim političkim zaleđem u zemlji1 ${ }^{16}$, koja zajedno s Oskarom Harmošem ponovno ${ }^{17}$ preuzima vodstvo zagrebačkog Baleta (1946. - 1953.). Roje je iznimno važna po osobnom pedagoškom angažmanu i suradnji Kazališta s tek pokrenutom Baletnom školom, koja je od osnutka 1949. imala cilj akademske baletne naobrazbe budućeg profesionalnog plesačkog kadra. Dolazak i rad iznimnih baletnih pedagoga i koreografa Milorada Jovanovića te potom Octavija Cintolesija učvrstio je sponu Kazališta i Škole, iz koje počinju izlaziti generacije baletnih plesača koje će razvidno podignuti izvedbenu razinu hrvatskog baleta.

Plesači u to vrijeme, kad su „ljudi su čekali od šest ujutro da se blagajna otvori u deset sati, a red je bio od blagajne do Kazališne kavane ${ }^{\text {"18 }}$, intenzivno rade na dvjema scenama (u Velikom i Malom kazalištu), a osim toga, imaju česte nastupe u Artističkoj pozornici „Varietéu“"19 i „Kerempuhovu vedrom kazalištu“ ${ }^{20}$ na Kaptolu koje je bilo vrlo popularno po kabaretsko-satiričkom programu. Tu se npr. igrala baletna jednočinka Druga rezolucija Kerempuhovog vedrog kazališta, po kojoj Milan Katić snima baletnu pantomimu Tajna dvorca I. B. (1951. $)^{21}$.

Iako rjeđe, Margarita Froman se koreografski javlja sve do 1955. godine, kad zauvijek odlazi u Ameriku. Iz tog je perioda zapamćena njezina poetična i originalna postava baleta Romeo i Julija (1948.). Froman je proslavljeni moderni balet Sergeja Prokofjeva postavila samo osam godina nakon sovjetske praizvedbe Lavrovskog pa je zagrebački balet prvi koji ga je izvodio u ovom dijelu Europe. (Balet je izveden i na gostovanju u Londonu 1955., no engleska kritika bila je puno naklonjenija drugom naslovu, baletu Đavo u selu Frana Lhotke te Pie i Pina Mlakara koji je smatrala primjerenijim i autentičnim izrazom hrvatskog baleta.)

\footnotetext{
To su bile: Vjera Marković, Beata Domić, Milana Broš, Nevenka Biđin, Sonja Kastl i Mirjana Dančuo.

Anin brat Ante Roje bio je narodni heroj.

17 Prvi put vode balet u HNK-u u Zagrebu od 1941. do 1943.

18 Jelena Minelčıć i M. Đurinović, „Razgovori: Rudi Zubčić, Jedno drukčije kazalište“, Vijenac (Zagreb), br. 230, 26. 12. 2002., 37-38.

19 Ilica 31, prije kino „Udarnik“, kasnije „Jazavac“, pa „Kerempuh“.

20 Kasnije „Komedija“.

21 U filmu, koji je na dulje vrijeme bio završio u bunkeru i tek je nedavno prikazan, igraju plesači zagrebačkog Baleta: Silva Hercigonja, Nenad Lhotka, Milko Šparemblek, Zvonimir Podkovac i Ladislav Sertić.
} 
Cintolesi je u Zagreb donio slutnju novog, modernog baleta, koji se počeo stvarati na Zapadu te poslije njegova odlaska dolazi do pravog plesačkog egzodusa. Čini se nevjerojatnim da je HNK u Zagrebu moglo napustiti više od 20 plesača $^{22}$, a da se svejedno nastavio razvoj Baleta, koji 1965. postaje samostalna grana unutar Kazališta. Jedan od prvih velikih spektakala na zagrebačkoj baletnoj sceni bilo je postavljanje Labuđeg jezera u koreografiji Rostislava Zaharova 1962., baleta u kojem će Maja Bezjak prva otplesati zahtjevnu ulogu bijelog i crnog labuda.

\section{2. Suvremena plesna scena}

Dok je balet nakon Drugog svjetskog rata nastojao uspostaviti kontinuitet, za suvremenu plesnu scenu, koju mnogi smatraju ostatkom građanskog elitizma 1945., sve počinje ispočetka. Od desetak plesnih umjetnica modernog usmjerenja koje su djelovale 1930-ih, rad nastavlja samo Ana Maletić ${ }^{23}$ (također Labanova učenica), koja je imala podršku jednog dijela kulturnopolitičkog vodstva i uspjela, nakon nekoliko neuspješnih pokušaja osnivanja Škole, tečajeva i ansambla, ponovno započeti povijest suvremenog plesa u Zagrebu: najprije osnutkom Škole za ritmiku i ples (1954.), a onda uz prve generacije mladih snaga, završenih učenica Škole, pokretanjem Studija za suvremeni ples. Studio vodi Anina kći Vera Maletić, koja između 1964. i 1967. (nakon čega odlazi u Englesku, pa u Ameriku) istražuje odnos plesa te filmske i videotehnologije, a njezini, tih godina nastali (srećom, i danas dostupni), radovi Formacije (1964.), Radiant (1966.) i Koreografija za kameru i plesače $e^{24}$ (1967.) svjedoče umjetničku radoznalost, sklonost eksperimentu i otvorenost novim medijima.

Iste godine, 1962., kada Ana i Vera Maletić izlaze s konceptom i programom Studija, samo nekoliko mjeseci ranije, pojavljuje se Milana Broš sa svojom Eksperimentalnom grupom slobodnog plesa (kasnije poznatom kao KASP - Komorni ansambl slobodnog plesa) koju formira u Pionirskom kazalištu (popularnom PIK-u) od talentiranih polaznika plesnog studija ${ }^{25}$. KASP i Studio dugo godina čine i razvijaju suvremenu, izvaninstitucionalnu plesnu scenu ${ }^{26}$. Njihova istraživanja, bliska principima umjetnosti 20. stoljeća, imaju podršku u dijelu kritike ${ }^{27}$, koja se zalaže za nove oblike prikladne suvremenom čovjeku. Karakterizira ih asketska čistoća linija tijela, podcrtana uskim crnim dresovima (u početku su to bili debeli, kruti materijali, koji su imali patentni zatvarač na leđima), bose noge i nastupi u čistim, ispražnjenim prostorima.

\footnotetext{
22 Svi su ostvarili impresivne umjetničke karijere: Irena Milovan, Mila Narandža, Anđelka Ilić, Vjera Marković, Sonja Marchioli, Nenad Lhotka, Milko Šparemblek, Frane Jelinčić, Veseljko Sulić, Miljenko Banović, braća Sertić, Zvonimir Podkovac, Ljuba i Petar Dobrijević, Zlatko Voženilek, Dragutin Boldin, Hrvoje Ježić, Žarko Prebil, Marijan Jagušt, Zvonimir Tajzl, Ivan Kramar i Jozo Borčić.

23 Više u: M. Đurinović, Razvoj suvremenog plesa: Ana Maletić, životopis, Zagreb 2008.

24 Suradnja Vere Maletić s Krešom Golikom. Više u: J. Minelčıć, „Koreografije Vere Maletić za kameru i plesače“, Kretanja, 30/2018., 61-65.

25 Nada Kokotović, Vlasta Spinčić, Olga Draušnik, Boris Pavlenić i Ivica Ivanko.

26 KASP u jednom periodu nalazi utočište u prostoru Studentskog centra: Muzičkom salonu i Teatru \&TD.

27 KASP je tih prvih godina posebno podržavao Stojan Dimitrijević, ali i Petar Selem te Igor Mandić.
} 


\section{3. Novi medij}

Iako su u ovom periodu baletni scenski spektakl i nezavisna plesna scena suprotstavljeni kao Istok i Zapad u naglašenom animozitetu, plesači i koreografi susreću se i surađuju u novim međuprostorima. $S$ jedne strane, to su ambiciozni i ozbiljni autorski projekti i programi „Muzičkog biennalea“ na kojima se domaći umjetnici upoznaju i supostavljaju uz vodeća imena svjetske avangarde. Usporedno se razvija i uzbudljivi novi televizijski medij, koji u početku ima ideju promoviranja suvremenih kompozitora koreografskom vizualizacijom glazbe ${ }^{28}$. S druge strane, i baletni i suvremeni plesni koreografi i plesači surađuju s Televizijom, otkrivajući komercijalne potencijale zabavnih programa koji polako, ali nezaustavljivo prodiru sa Zapada.

\section{$\cos$}

\section{THE BEGINNINGS OF THE CONTEMPORARY DANCE SCENE IN ZAGREB I924 - I930 AND I945 - I967}

Summary: The years which Vladan Desnica spent in Zagreb coincide with two strong waves of Europeization and growth; one of the many new interests, artistic ideas and practices that were being adopted at the time was dance. This paper provides a short overview of the development of the Croatian dance scene, drawing from the research I have conducted over twenty years, and a number of articles I have published. I would point the interested reader towards texts accompanying the great thematic exhibitions: "Avant-garde tendencies in Croatian Art", "Passion and rebellion/ Expressionism in Croatia" and "The Sixties in Croatia: Myth and Reality" for additional information on the period defined by the title.

The history of the Croatian dance scene is distinctive because of the concurrent development of ballet and modern dance. The two key events in this development occurred in 1924, when Russian ballet artist Margarita Froman, who had set the foundations for the national ballet scene three years earlier, choreographed The Gingerbread Heart, set to music by Krešimir Baranović and with an outstanding guest appearance by Rudolf Laban, which in turn led to the opening of schools of the expressive modern dance Ausdruckstanz. These are also the circumstances in which the first Croatian prima ballerina and one of the great ballet dancers of her time, Mia Čorak Slavenska developed as an artist.

Following the war and the ensuing political changes, efforts were made to form cultural institutions which would showcase the achievements of the newly-established SFRY. The Ballet of the Croatian National Theater weathered this tumultuous early period under the tutelage of the internationally acclaimed artists Ana Roje and Oskar Harmoš. They endorsed the founding of the Zagreb School of Ballet, while Laban's protégée Ana Maletić, virtually the only remaining representative of modernism in dance, established the School of Rhythmics and Dance. This, along with the rare but significant appearances by notable guest educators from abroad, pushed the craft towards professionalism. In the 1960s, as the access to the West became easier, Zagreb was re-established as a cultural center and a point of origin for new artistic tendencies, while a well-respected ballet and contemporary dance scene emerged.

$\overline{28}$ Urednik Vlado Seljan i redatelj Mladen Raukar posebno su aktivni na tom glazbeno-scenskom području. 
Key words: the Ballet of the Croatian National Theater in Zagreb, modernism in dance, the independent dance scene

\section{$\cos$}

\section{Izvori}

Vinko Jurković, „Kazalište i umjetnost“, Slobodna tribuna (Zagreb), br. 542, 21. 6. 1924., 6.

Kalman Mesarić, „Apsolutni ples. Gostovanje teatra R de Labana“, Slobodna tribuna (Zagreb), br. 538, 24. 5. 1924., 11.

Mia Čorak / brošura, izbor kritika baletnih nastupa Mie Čorak od 1922. do 1932., 1933. [?], 7-8. Jelena Minelčić i Maja Đurinović, „Razgovori: Rudi Zubčić, Jedno drukčije kazalište“, Vijenac (Zagreb), br. 230, 26. 12. 2002., 37-38.

Scena (Zagreb), 21. 5. 1924., 6.

\section{Literatura}

Andrea Amort i Mimi Wunderer-Gosch, Österreich tanzt. Geschichte und Gegenwart, Beč 2001.

Maja Đurinović, „Balet“, u: Hrvatsko narodno kazaliste u Zagrebu 1840 - 1860 - 1992, Zagreb 1992., 153-181.

Maja Đurinović, Razvoj suvremenog plesa: Ana Maletić, životopis, Zagreb 2008.

Maja Đurinović, „Vera Milčinović Tashamira: Plesna umjetnica koja je donijela europski izražajni ples u Ameriku (Zvali su je Croatian Beauty)“, u: Krležini dani u Osijeku 2016. Hrvatska drama i kazaliste u inozemstvu: drugi dio, Zagreb - Osijek 2017.

Maja Đurinović i Zvonimir Podkovac, Mia Črak Slavenska, Zagreb 2004.

Jelena Mıнelčıć, „Koreografije Vere Maletić za kameru i plesače“, Kretanja, 30/2018., 61-65.

Iva Nerina SibILA, „Ples je rasno pitanje / Rudolf Laban i nacistički režim“, Kretanja, 27/2017., $25-31$.

Katarina ŽeraviCA, „Škola za ritmičku gimnastiku i umjetnički ples Gertrud Kraus“, Književna revija, 56/2016., br. 1-2, 34. 


\section{Prilozi}

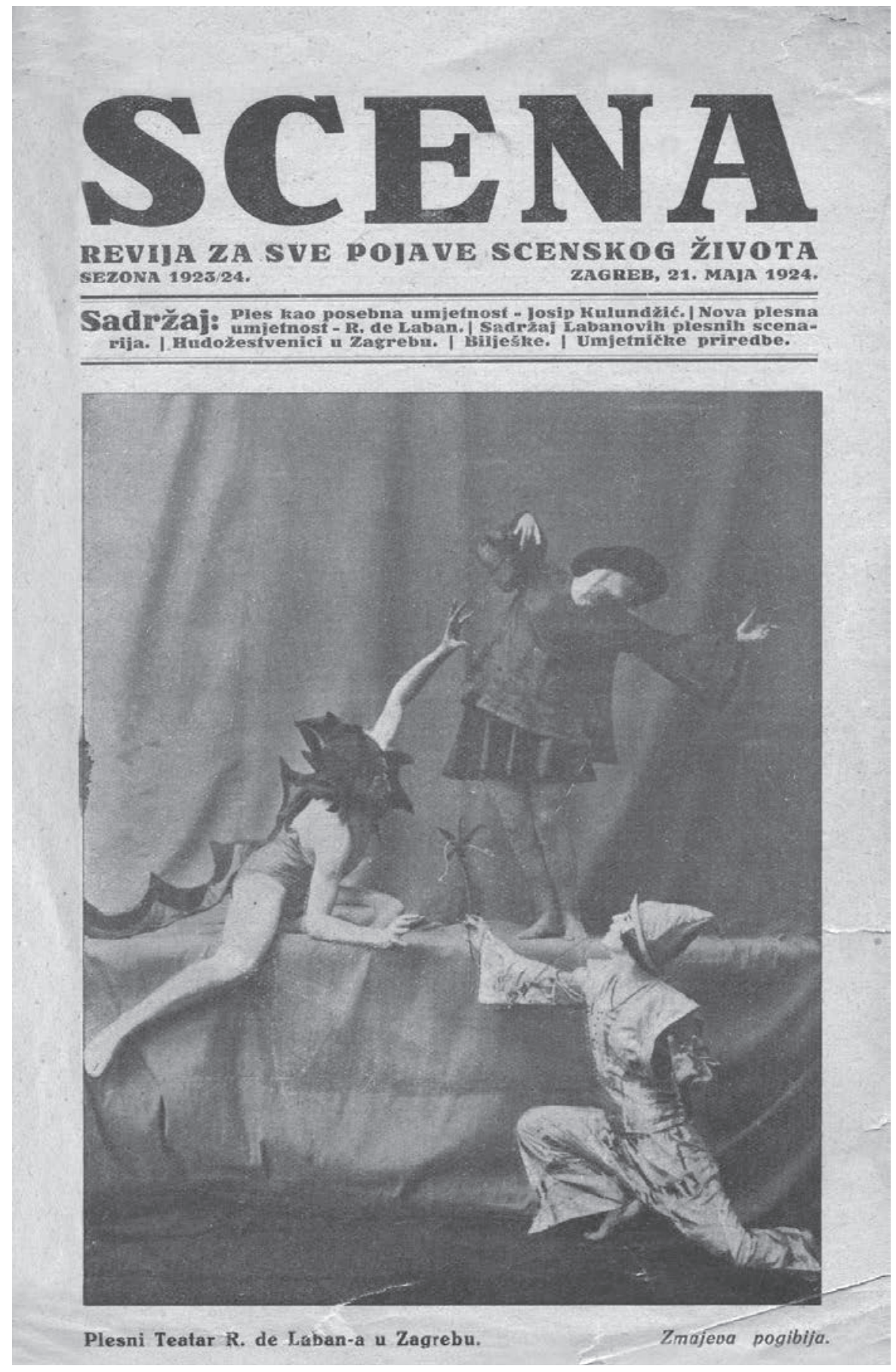

Sl. 1. Plesni teatar R. de Laban na naslovnici zagrebačke Scene (1924.) 


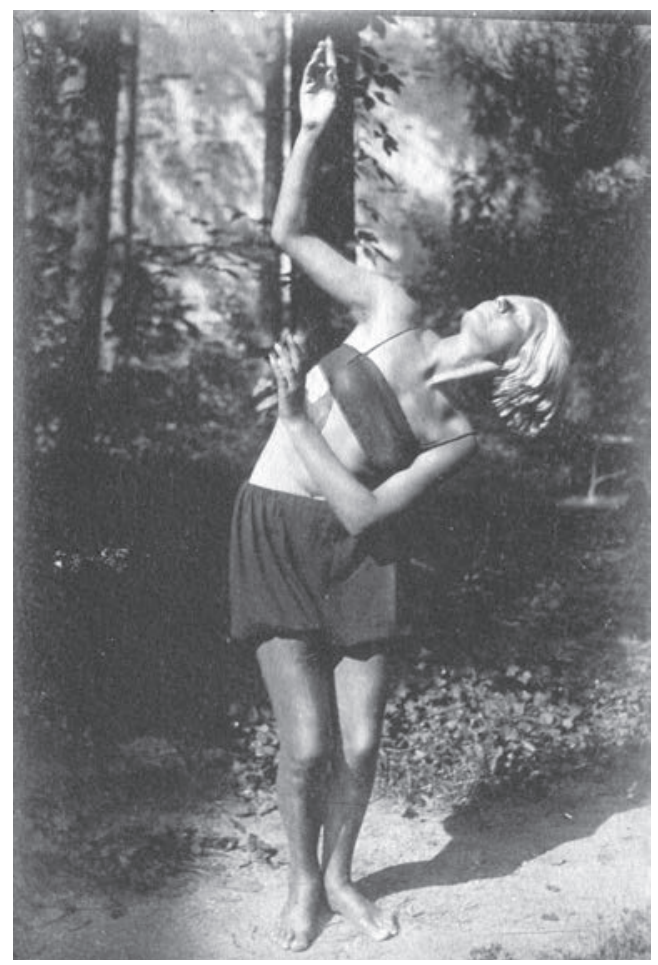

Sl. 2. Vera Milčinović Tashamira u Maksimiru, 1925.

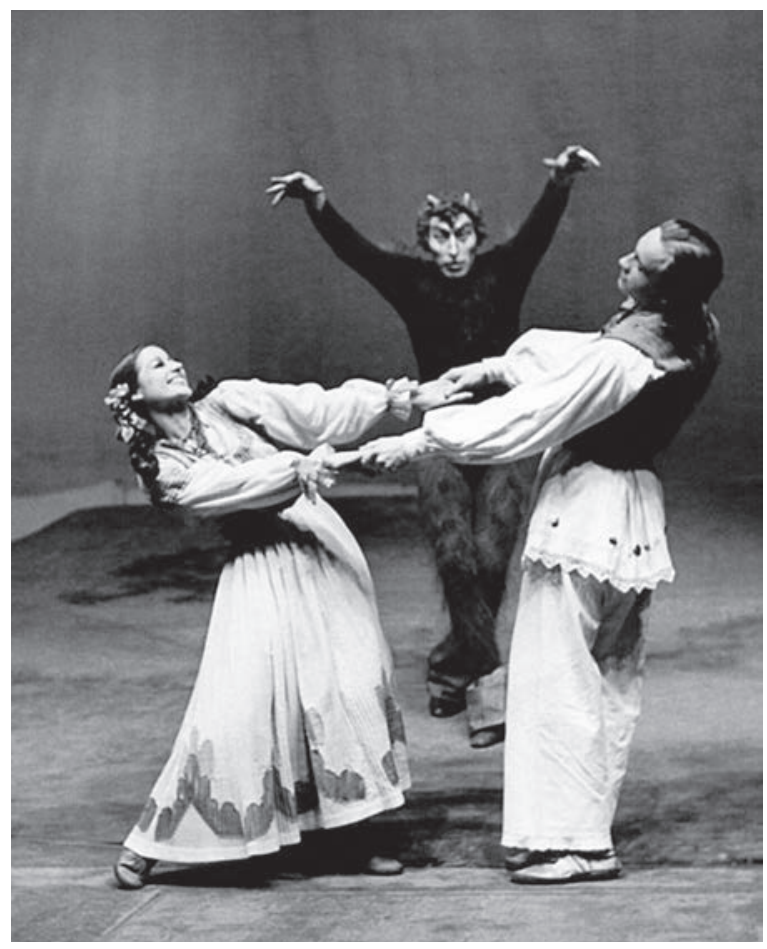

Sl. 3. Đavo u selu, Zagreb, 1945. - Ana Roje, Oskar Harmoš i Nenad Lhotka 


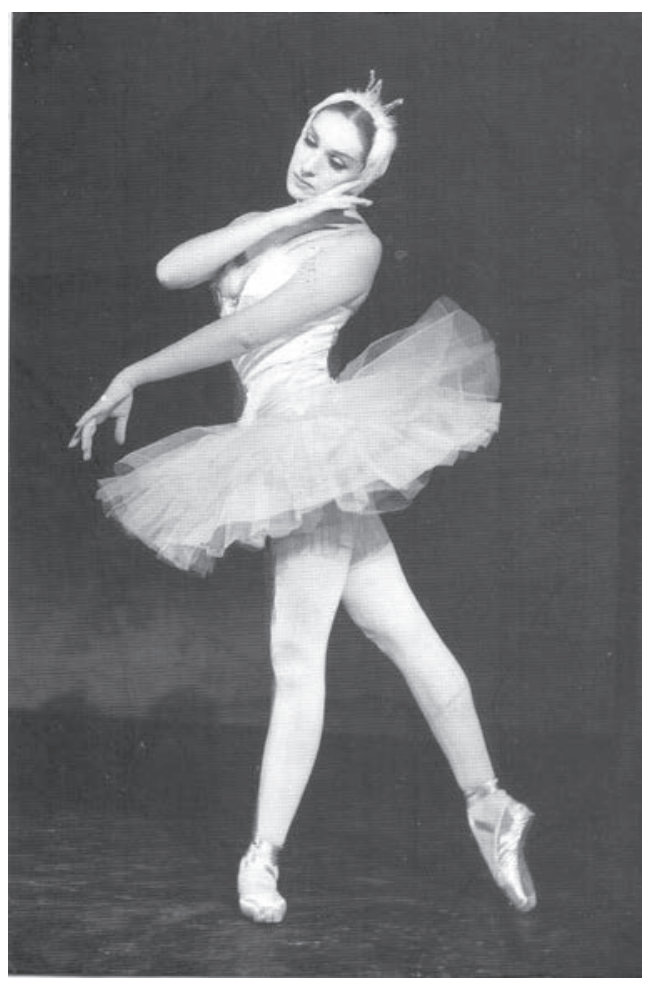

Sl. 4. Maja Bezjak kao Odette, Zagreb, 1962.

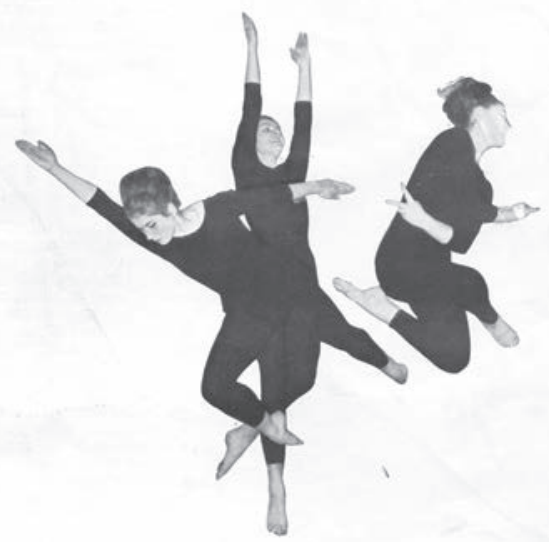

\section{Škola za ritmiku i ples}

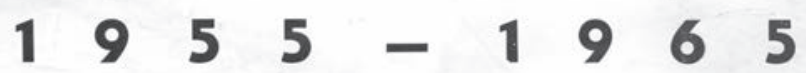

Sl. 5. Škola za ritmiku i ples - prostorni akord u skoku (Tihana Škrinjarić, Ivanka Cerovac i Ljiljana Putz) 
